\title{
A novel bispecific c-MET/PD-1 antibody with therapeutic potential in solid cancer
}

\author{
Zu-Jun Sun ${ }^{1, *}$, Yi Wu ${ }^{1, *}$, Wei-Hua Hou ${ }^{1}$, Yu-Xiong Wang ${ }^{1}$, Qing-Yun Yuan ${ }^{1}$, Hui-Jie \\ $\mathbf{W a n g}^{2}$, Min $\mathbf{Y u}^{1}$ \\ ${ }^{1}$ Key Laboratory of Metabolism and Molecular Medicine, Ministry of Education and Department of Biochemistry and Molecular \\ Biology, School of Basic Medical Science, Fudan University, Shanghai, China \\ ${ }^{2}$ Department of Medical Oncology, Shanghai Cancer Center and Department of Oncology, Shanghai Medical College, Fudan \\ University, Shanghai, China \\ "These authors have contributed equally to this work \\ Correspondence to: Hui-Jie Wang, email: wanghj98@hotmail.com \\ Min Yu, email: minyu@shmu.edu.cn
}

Keywords: cellular-mesenchymal to epithelial transition factor, programmed death-1

Received: September 13, 2016

Accepted: January 24, 2017

Published: March 14, 2017

Copyright: Sun et al. This is an open-access article distributed under the terms of the Creative Commons Attribution License (CC$\mathrm{BY})$, which permits unrestricted use, distribution, and reproduction in any medium, provided the original author and source are credited.

\section{ABSTRACT}

The bispecific antibody is a novel antibody, which can target two different antigens and mediate specific killing effects by selectively redirecting effector cells to the target cells. Here, we designed and synthesized a bispecific antibody (BsAb) that can bind cellular-mesenchymal to epithelial transition factor (C-MET, overexpressed in several human solid tumor), and programmed death-1 (PD-1, involved in cancer cell immune evasion) with high affinity and specificity. We found that BsAb can induce the degradation of C-MET protein in cancer cells, including MKN45, a gastric cancer cell line, and A549, a lung cancer cell line. BsAb inhibited hepatocyte growth factor (HGF)-mediated proliferation, migration, and antiapoptosis, and downregulated HGF-stimulated phosphorylation of C-MET, protein kinase B (AKT), and extracellular signal-regulated kinase (ERK1/2). BsAb can also rescue T cell activation. Furthermore, xenograft analysis revealed that BsAb markedly inhibits the growth of subcutaneously implanted tumors and chronic inflammation. On the basis of these results, we have identified a potential bispecific drug, which can effectively target C-MET and PD-1 for the treatment of human solid cancers.

\section{INTRODUCTION}

Cellular-mesenchymal to epithelial transition factor (c-MET) is confirmed as the only high affinity receptor that binds hepatocyte growth factor (HGF) [1], which mediates cell morphogenesis, mitogenesis, angiogenesis, and cytoprotection in vitro $[2,3]$. c-MET is overexpressed in a broad spectrum of human solid tumors [2, 4], and once activated, promotes tumor progression, invasion, metastasis, and angiogenesis [5]. c-MET is also overexpressed in human glioblastomas, and expression levels correlate with glioma malignancy grade and vascularity, promoting glioma growth and angiogenesis in vivo [5-10]. Activation of the HGF/c-MET pathway in various solid tumors can stimulate lymphangiogenesis, leading to lymph node metastasis [11]. Consequently, c-MET has become a leading target candidate for cancer therapy. Currently, commercial c-MET inhibitors used in second-line treatment in phase 2 clinical trials significantly prolong progression time and survival of patients with hepatocellular carcinoma [12, 13]. However, several in vivo studies published showed that some c-MET inhibitors carry potential side effects, such as heart rate acceleration, cardiac muscle denaturation, renal toxicity, and body weight reduction [14-16]. Following clinical trials, monoclonal antibodies against growth factors or their receptors have been approved for cancer therapy. Nevertheless, targeting c-MET with monoclonal antibodies has proved difficult because most antibodies have intrinsic agonistic activity $[17,18]$. 
Programmed death-1 (PD-1) is an immunoglobulin superfamily member expressed on activated and exhausted T cells, which can also recruit regulatory T (Treg) cells [19]. Programmed death-ligand 1 (PD-L1), the primary ligand for PD-1, is broadly expressed by most cell types, including dendritic cells (DCs), as well as by tumor cells [20-22]. Upon ligation, the PD-1/PD-L1 pathway recruits Src homology 2 domain-containing phosphatase-2 (SHP-2) to control peripheral tolerance $[19,23]$. PD-L1 is upregulated in the tumor microenvironment in response to inflammatory stimuli, and the PD-1/PD-L1 pathway can inhibit T cellmediated anti-tumor responses [23, 24]. Monoclonal antibodies blocking coinhibitory immune checkpoint receptors (e.g., PD-1/PD-L1) show remarkable efficacy against many cancers. For example, anti-PD-1 antibody produced objective clinical responses in approximately 20 $25 \%$ of patients with non-small-cell lung cancer (NSCLC), melanoma, and renal-cell cancer [25, 26], and anti-PD-1/ PD-L1 showed objective responses in NSCLC as a monotherapy, with evidence for markedly increased overall survival in second-line treatment reported in patients with adenocarcinoma and squamous cell carcinoma [27-30]. Recently, the FDA approved two agents blocking PD-1 (nivolumab and pembrolizumab) for the treatment of metastatic melanoma [31, 32]. Ipilimumab, a monoclonal antibody that works to activate the immune system by targeting CTLA-4, combined with nivolumab attained intense and synergistic therapeutic effects in the treatment of a deadly form of skin cancer [33-34]. Ipilimumab combined with chemotherapy showed a modest degree of clinical activity in the treatment of patients with metastatic NSCLC [35]. However, it has to be noted that systemic administration of PD-1/PD-L1 blocking antibodies carries potential side effects, such as persistent high fever and breakdown of peripheral tolerance [36].
In the present study, a novel targeted c-MET and PD-1 BsAb was developed in our laboratory, that can bind human c-MET and PD-1 with high affinity and specificity, and induce the degradation of c-MET in multiple cancer cell types, including MKN45, a gastric cancer cell line, and A549, a lung cancer cell line. Our BsAb can inhibit HGFinduced growth and migration of c-MET-addicted tumor cells, promote the apoptosis of tumor cells, and rescue IL-2 secretion of Jurkat T cells. BsAb can also inhibit HGFstimulated c-MET autophosphorylation of Tyr1234/1235 in the activation loop, which activates downstream molecules, such as protein kinase B (AKT) and extracellular signalregulated kinase (ERK). We have further identified that our $\mathrm{Bs} A \mathrm{~b}$ could potently inhibit tumor growth and inflammatory factor secretion in vivo, implicating its immunotherapeutic potential in human solid tumor treatment.

\section{RESULTS}

\section{Expression of c-MET and PD-L1 by tumor cells}

First, we evaluated c-MET and PD-L1 mRNA expression in eight human cancer cell lines using realtime quantitative polymerase chain reaction (qPCR). All eight cell lines expressed c-MET at a relative high levels, but only four (MKN45, MDA-MB-231, A549, and IM95) expressed PD-L1 at a relative high levels (Figure 1A). Next, we detected c-MET protein expression by western blot. The results showed that all eight cancer cell lines also expressed c-MET protein at a relative high levels (Figure 1B). Finally, we determined whether the above eight cancer cell lines can produce xenografts in NOD/SCID mice. Three of the eight cell lines produced xenografts well (MKN45, A549, and IM95) (data not shown), hence, MKN45 and A549 cell lines were selected for use in this study, both of which express
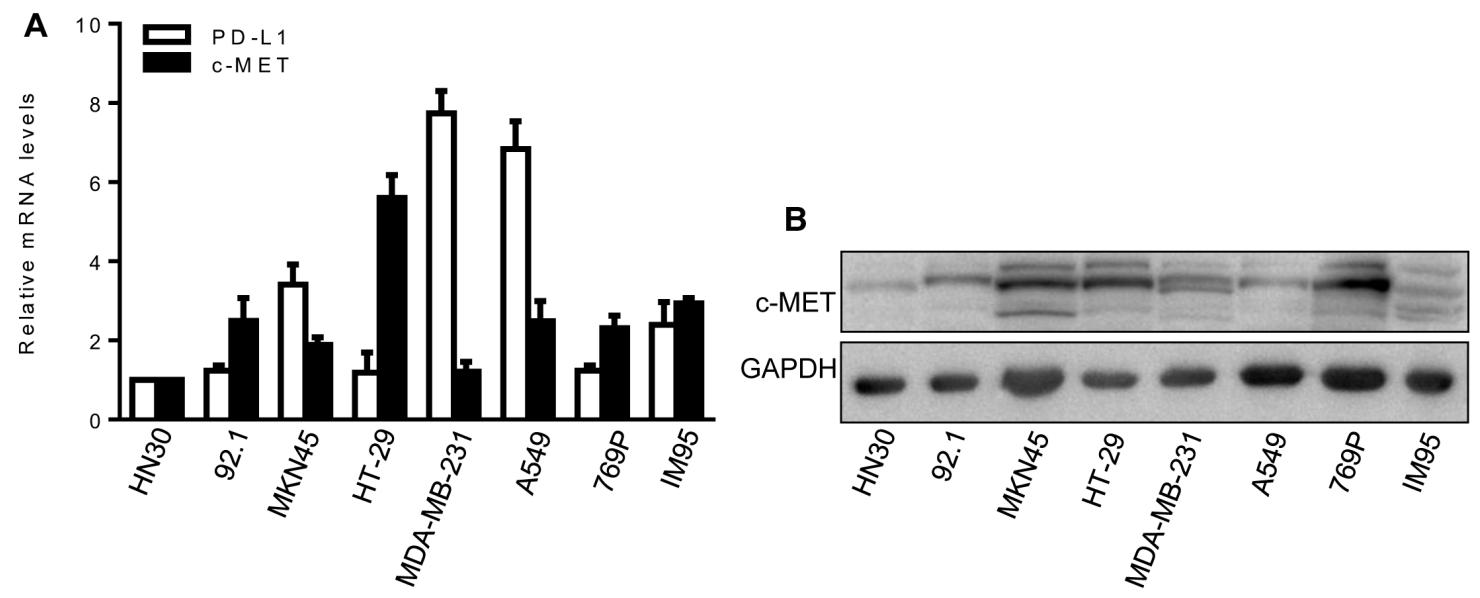

Figure 1: Expression of c-MET and PD-L1 in cancer cell lines. (A) c-MET and PD-L1 mRNA expression were detected by qPCR. HN30 cells as the calibrator sample. Each experiment was repeated three times. (B) c-MET protein expression was detected by western blot analysis. GAPDH expression was used as an internal control. 
relative high levels of c-MET and PD-L1, and effectively produce xenografts.

\section{BsAb inhibits HGF-stimulated cancer cell proliferation, migration, and antiapoptosis}

Our BsAb has two targets, and can block c-MET and PD-1. To test the effect of BsAb targeting of c-MET on tumor cells growth, tumor cells were treated with or without BsAb for $8 \mathrm{~h}$ and JNJ 38877605 (JNJ, a known c-MET inhibitor) for $2 \mathrm{~h}$ before HGF treatment. Cell viability was then measured using the MTS assay. BsAb significantly inhibited cancer cell growth, and had the same effect as JNJ (Figure 2A). In migration assays, BsAb significantly inhibited MKN45 and A549 cells migration (Figure 2B). The same effect was observed in JNJ treated group (Figure 2B).
c-MET rescued apoptosis in renal cancer cells [37], and inhibition of c-MET signaling increased mitochondrial release of cytochrome $\mathrm{C}$ and the $\mathrm{Bax} / \mathrm{Bcl} 2$ ratio [38]. We therefore evaluated the effect of BsAb on c-MET-mediated signaling in the regulation of cancer cell death. Tumor cells were treated with BsAb for $8 \mathrm{~h}$ or JNJ for $2 \mathrm{~h}$, and then treated with combinations of HGF and rapamycin (RAPA) for $48 \mathrm{~h}$. Cells were stained with annexin $\mathrm{V}$ and propidium iodide (PI), and analyzed by flow cytometry to measure the apoptotic index. HGF significantly rescued RAPA-induced cellular apoptosis (Figure 2C, left), with a reduction from $20.67 \%$ to $9.43 \%$ in MKN45 cells; nevertheless, our BsAb markedly inhibited this effect. With BsAb pre-treatment, the percentage of RAPA-induced apoptotic MKN45 cells increased from $9.43 \%$ to $17.17 \%$. JNJ produced the same effect as BsAb, and the same phenomenon was shown in A549 cells (Figure 2C, right). Altogether, our results indicate

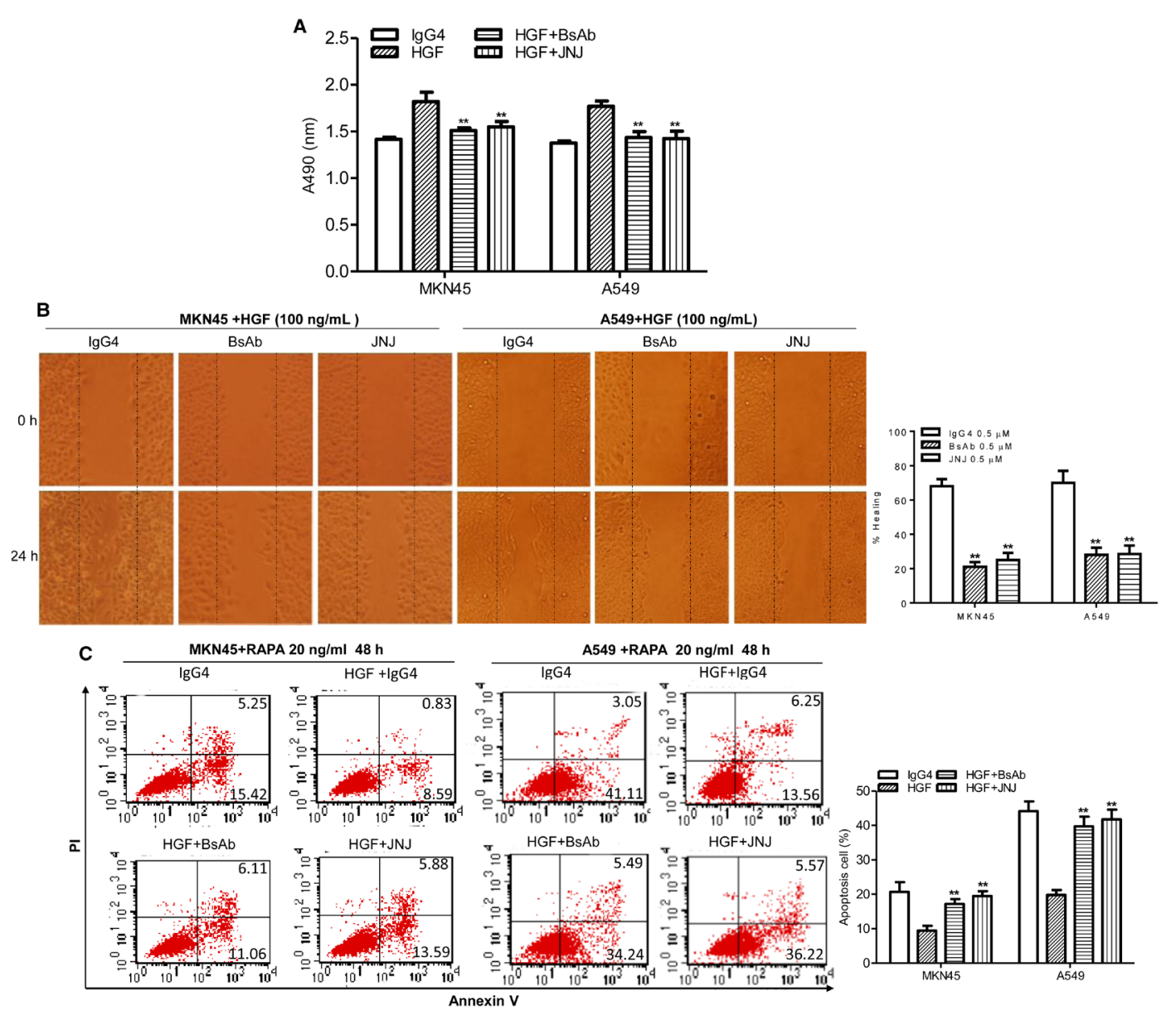

Figure 2: BsAb inhibits HGF-induced cancer cells proliferation, migration, and apoptosis resistance. (A) The viability of MKN45 and A549 cells were assessed by MTS assay after treatment with HGF (100 ng/mL), IgG4 (0.5 $\mu \mathrm{M}), \mathrm{BsAb}(0.5 \mu \mathrm{M})$, and JNJ (0.5 $\mu \mathrm{M}$ ) for $72 \mathrm{~h}$. Each experiment was repeated 3 times. $* *$ : $P<0.01$. (B) Wound healing assay. Cancer cells were cultured to confluency on plastic dishes. Next day a linear scrape wound was made using a sterile tip, and cells were treated as described in the materials and methods section. (Original magnification, 100×). Each experiment was repeated 3 times. $* *: P<0.01$. (C) Cancer cells were incubated with BsAb $(0.5 \mu \mathrm{M})$ for $8 \mathrm{~h}$ or JNJ $(0.5 \mu \mathrm{M})$ for $2 \mathrm{~h}$ and then treated with combinations of HGF $(100 \mathrm{ng} / \mathrm{mL})$ and RAPA. After $48 \mathrm{~h}$ treatment, apoptotic cells stained with annexin $\mathrm{V}$ and propidium iodide, and analyzed by flow cytometry. Each experiment was repeated 3 times and the results were shown mean $\pm \mathrm{SD}$. **: $P<0.01$. 
that BsAb inhibits HGF-mediated proliferation, migration, and antiapoptosis effects in cancer cells, and could serve as an inhibitory c-MET antibody.

\section{BsAb inhibits HGF-triggered c-MET downstream molecules and promotes c-MET degradation}

The HGF/c-MET signal pathway plays a significant role in tumor development and metastasis [39], often through activation of downstream molecules, including AKT and ERK1/2 pathways. In the present study, we found that HGF-mediated upregulation of p-c-MET in MKN45 and A549 cells was completely inhibited with $\mathrm{BsAb}$ treatment, even more profoundly efficiency than JNJ treatment (Figure 3). Upregulation of p-AKT was observed in response to HGF stimulation that was also inhibited by BsAb and JNJ. Furthermore, upregulation of p-ERK1/2 was also inhibited by BsAb and JNJ treatment.

Quercetin and anti-c-MET antibodies can inhibit HGF/c-MET signaling by promoting c-MET protein degradation [40]. To clarify whether BsAb could induce c-MET degradation, western blot analysis was performed to assess c-MET stability. BsAb strongly downregulated c-MET protein expression in both dose- and timedependent manners in the two cancer cell lines (Figure 4A, 4B). However, there was no effect on c-MET mRNA expression, assessed by qPCR (Figure 4C, 4D). These results suggest that the AKT and ERK1/2 pathways play an essential role in cancer cell proliferation, migration, and apoptosis, and BsAb could prove to be an effective inhibitor of cancer development, via c-MET targeting.

\section{BsAb promotes IL-2 production by Jurkat T cells}

Cytokine secretion is an important criterion for evaluating T cell function. To assess the effect of MKN45 and A549 cell expression of PD-L1 on T cell function, Jurkat $\mathrm{T}$ cells were cocultured with IFN- $\gamma$-pretreated MKN45 and A549 cells at different E:T proportions in the presence of PHA for $48 \mathrm{~h}$, and then tested for IL-2 production by ELISA. Jurkat $\mathrm{T}$ cells were shown to express PD-1 at low levels, however, approximately 36\% of Jurkat T cells expressed PD-1 after stimulation with PHA $(1 \mu \mathrm{g} / \mathrm{mL})$ for $48 \mathrm{~h}$ (Figure $5 \mathrm{~A})$. The relative mRNA expression of PD-L1 upregulated with IFN- $\gamma$ stimulation for $48 \mathrm{~h}$ (Figure $5 \mathrm{~B}$ ).

MKN45 and A549 cells cocultured with Jurkat T cells at an E:T of 5:1 significantly reduced Jurkat $\mathrm{T}$ cell IL-2 production (Figure $5 \mathrm{C}, 5 \mathrm{~F}$ ). In a co-culture system, MKN45 and A549-associated inhibition of IL-2 secretion was shown to be cell-contact-dependent; IL-2 levels were significantly inhibited in Jurkat $\mathrm{T}$ cells cocultured in contact with MKN45 and A549 cells $(P<0.01)$, compared to those in separated coculture. At the same time, the transwell coculture of cancer cells and Jurkat T cells also inhibited the secretion of IL-2 at lower levels (Figure 5D, $5 \mathrm{G})$.

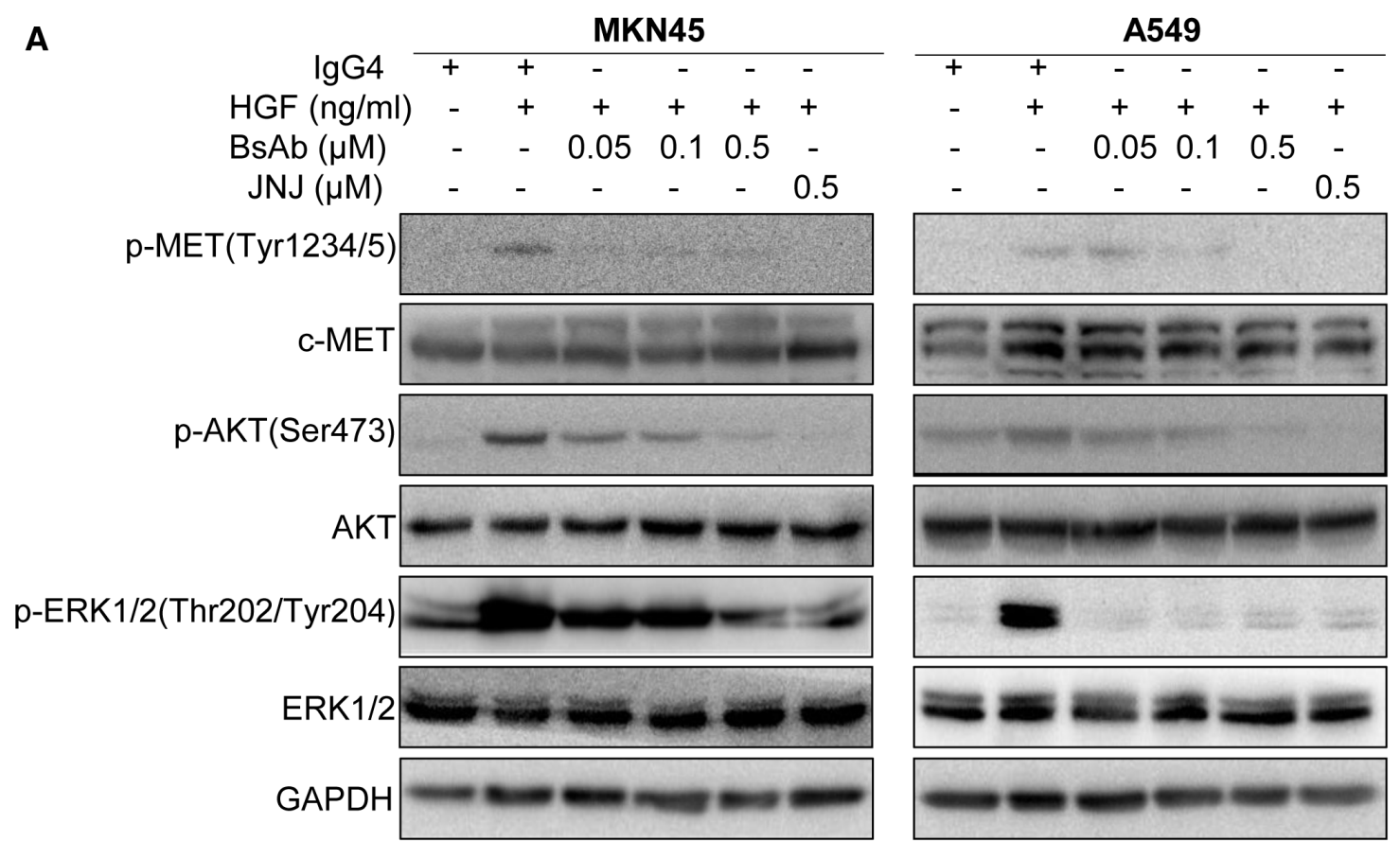

Figure 3: BsAb inhibits HGF-induced c-MET and its downstream molecules. (A) MKN45 and A549 cells were treated with the indicated concentrations of BsAb for $8 \mathrm{~h}$ or JNJ for $2 \mathrm{~h}$, and then stimulated with or without HGF (100 ng/mL) for $30 \mathrm{~min}$. Total cell lysates were evaluated by western blot using specific antibodies. GAPDH expression was used as an internal control. 

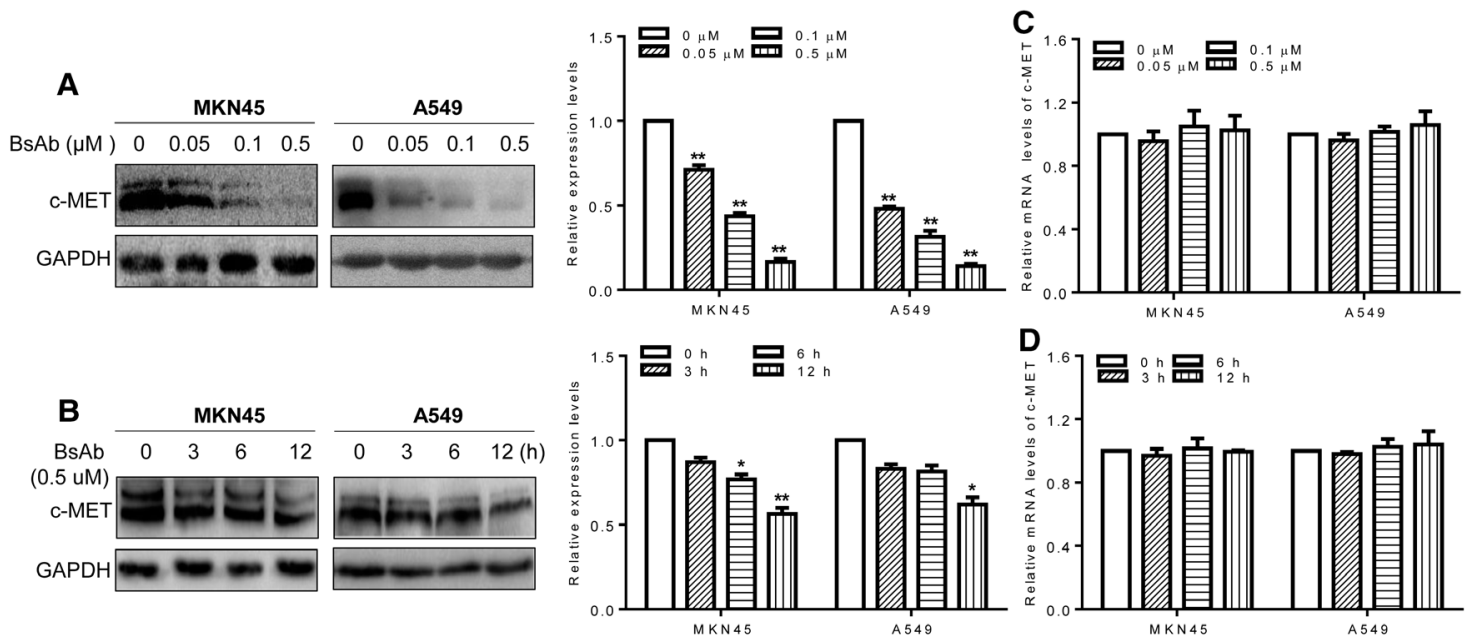

Figure 4: BsAb promotes c-MET protein degradation. (A, B) Cells were treated with the indicated concentrations of BsAb for 24 $\mathrm{h}$ (A) or for the indicated time (B). Total cell lysates were evaluated by western blot using anti-c-MET antibodies. Relative c-MET mRNA expression was evaluated by qPCR. (C, D) Cells were treated with the indicated concentrations of BsAb for $24 \mathrm{~h}(\mathbf{C})$ or for the indicated time (D). BsAb $(0 \mu \mathrm{M}$ or $0 \mathrm{~h})$ treatment as the calibrator sample. Above assays were repeated three times and the results were shown as mean \pm SD. *: $P<0.05$;*: $P<0.01$
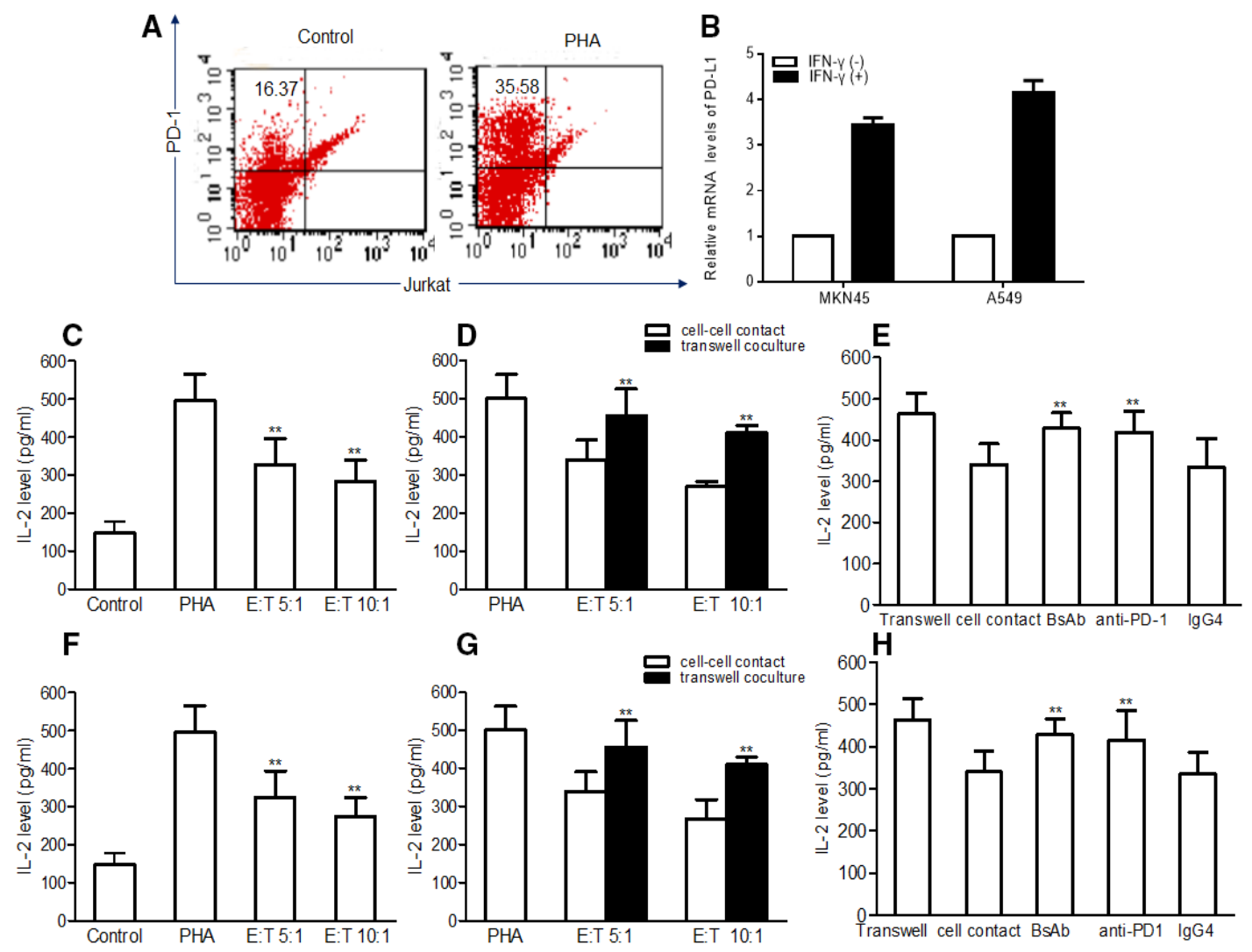

Figure 5: PD-L1 inhibits IL-2 production by human Jurkat T cells. MKN45 and A549 cells were pretreated with IFN- $\gamma$ (500 U/ $\mathrm{mL}$ ) for $48 \mathrm{~h}$, washed and cocultured with human Jurkat T cells, either with cell contact or in transwell coculture, in the presence of PHA $(1 \mu \mathrm{g} / \mathrm{mL})$ for $48 \mathrm{~h}$. IL-2 production was detected by ELISA. (A) The expression of PD-1 in Jurkat T cells with or without PHA stimulation by flow cytometry. (B) The relative mRNA expression of PD-L1 in cancer cell lines, with or without IFN- $\gamma$ stimulation, detected by qPCR. IFN- $\gamma(-)$ as the calibrator sample. (C, F) Inhibition of IL-2 production by Jurkat T cells in coculture with MKN45 (C) and A549 cells (F) at different E:T proportions. (D, G) Enhanced IL-2 production in transwell cocultures in MKN45 cells (D) and A549 cells (G). (E, H) Restoration of IL-2 production by addition of BsAb to Jurkat T cell-contact cocultures with MKN45 cells (E) and A549 cells (H). The assays were repeated three times and each sample has 3 holes, the results were shown as mean $\pm \mathrm{SD}$. **: $P<0.01$. 
In order to verify that the cell-contact-dependent inhibition of IL-2 secretion was due to PD-L1:PD-1 interaction, $\mathrm{BsAb}$ or IgG4 controls were added to the coculture systems. BsAb restored the secretion of IL-2 by Jurkat $\mathrm{T}$ cells by more than $40 \%$. However, addition of IgG4 control had no effect on IL-2 secretion by Jurkat T cells (Figure 5E, 5H).

From above results, we concluded that our BsAb can restore cytokine secretion by activated $\mathrm{T}$ cells, via interaction with PD-1, which may occur by blocking the PD-L1:PD-1 pathway.

\section{BsAb inhibits tumor development and inflammatory cytokine secretion in vivo}

Finally, we evaluated the effect of $\mathrm{BsAb}$ on tumor development by heterotopic xenograft analysis in vivo. NOD/SCID mice were subcutaneously injected with MKN45 cells. After 7 days, BsAb and IgG4 were administered twice a week for 3 weeks. PBMC were injected the first and fourth time drugs were administered through the tail vein. BsAb significantly inhibited MKN45induced tumor growth compared to IgG4, reducing the tumor volume by nearly $60 \%$ (Figure 6A), and inhibited tumor weight by approximately 50\% (Figure 6B). The body weight change of mice was not significant difference (data not shown). Moreover, immunohistochemical analysis showed that $\mathrm{BsAb}$ significantly reduced $\mathrm{Ki}$ 67, VEGF-A, and MMP-9 staining (Figure 6C), which indicates it may inhibit cell proliferation, angiogenesis, and metastasis in vivo. In addition, we found that $\mathrm{BsAb}$ reduced the secretion of inflammatory cytokines in vivo (including IL-6, but not TNF- $\alpha$ ) compared with control mice (Figure 6D), which suggests that BsAb treatment can inhibit chronic inflammation in vivo.

\section{BsAb inhibits tumor development beyond PD-1 antibody blockade in vivo}

The therapeutic efficacy of BsAb against MKN45 cell xenograft tumors was explored, and compared with PD-1 antibody and a one arm c-MET antibody. Mice were treated with IgG4, BsAb, PBMC iv + PD-1 ip antibody, or PBMC iv + BsAb ip. As shown in Figure 7A, PBMC $+\mathrm{BsAb}$ treatment significantly inhibited tumor size compared to treatment with BsAb alone $(P=0.005)$, or PBMC + PD-1antibody $(P=0.037)$. These data collectively suggest $\mathrm{BsAb}$ is a more potent inhibitor of tumor growth in vivo than PD-1 or one arm c-MET antibody.

\section{DISCUSSION}

$\mathrm{BsAb}$ can redirect specific immune cells to tumor cells to enhance tumor killing, enablethe simultaneous blocking of two different antigens that exert unique or overlapping roles in pathogenesis, and can potentially increase binding specificity by interacting with two different cellular surface antigens instead of one [41]. $\mathrm{BsAb}$ are a promising way of enhancing anti-tumor immunity in immunotherapy with the goal of achieving synergistic effects. BsAb can interfere with multiple surface receptors or ligands associated with cancer cell proliferation or inflammatory processes. For example, BsAb simultaneously targeting EGFRx c-MET produced synergies that inhibited tumor proliferation and metastasis more effectively [42-44]. With the development of genetic engineering utilizing recombinant DNA technology, more than $30 \mathrm{BsAbs}$ have so far been exploited in a clinical setting. Currently, two of the front-runners have been approved for the market by the FDA for the treatment of pro-B cell acute lymphocyte leukemia (ALL) and malignant ascites, and several more are in clinical trials $[45,46]$.

A novel, targeted c-MET and PD-1 humanized bispecific monoclonal antibody was developed in our laboratory, which can bind both c-MET and PD-1 cellular surface antigens with high affinity and specificity. Theoretically, our BsAb could inhibit tumor progression, migration, metastasis, and angiogenesis by blocking c-MET, and can also rescue systemic $\mathrm{T}$ cell function by blocking PD-1 in cancer cells overexpressing c-MET and PD-L1. Moreover, our BsAb could form a bridge between $\mathrm{T}$ cells and tumor cells, allowing the T cells to target the tumor cells directly.

Previous attempts to target c-MET with antibodies have met with difficulty, because most antibodies have intrinsic agonistic activity [47, 48], and the effects of individual antibodies were minimal. The divalent structure of antagonistic antibodies directed to c-MET often activates c-MET signaling pathway via receptor dimerization and cross-activation, which appear to function as agonists. Recently, however, a novel onearmed variant of the c-MET antibody 5D5 (OA5D5) was developed by Genentech (South San Francisco, CA), which acts as a pure antagonist, and can inhibit the growth of cells dependent on HGF/c-MET autocrine and paracrine signaling, and inhibit glioma growth in an orthotopic model in vivo $[49,50]$. The monovalent format antibodies proved to be necessary against the agonistic activity [51]. In the present study, we have successfully developed a novel BsAb targeting c-MET and PD-1, using monovalent forms of anti-c-MET and anti-PD-1, which can avoid inducing c-MET receptor dimerization, and the intrinsic agonistic activity, just as OA5D5 can.

In vitro, our $\mathrm{BsAb}$ inhibited $\mathrm{HGF}$-induced growth and migration of c-MET-addicted tumor cells (Figure 2A, 2B), and promoted apoptosis in tumor cells (Figure 2C), even more effectively than JNJ, a known c-MET inhibitor. BsAb also inhibited HGF-stimulated c-MET autophosphorylation of Tyr1234/1235 in the activation loop, which activates downstream molecules, such as AKT and ERK1/2 (Figure 3). It is well known that 


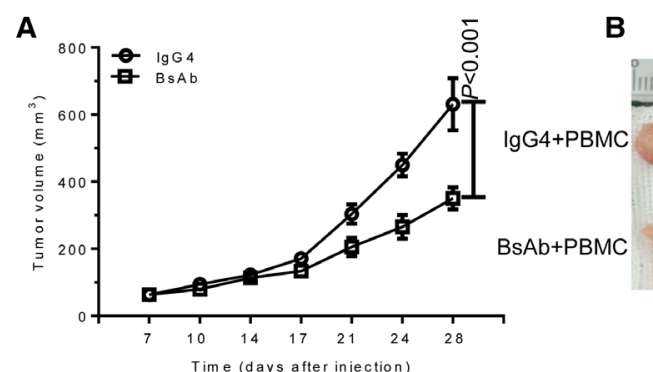

B
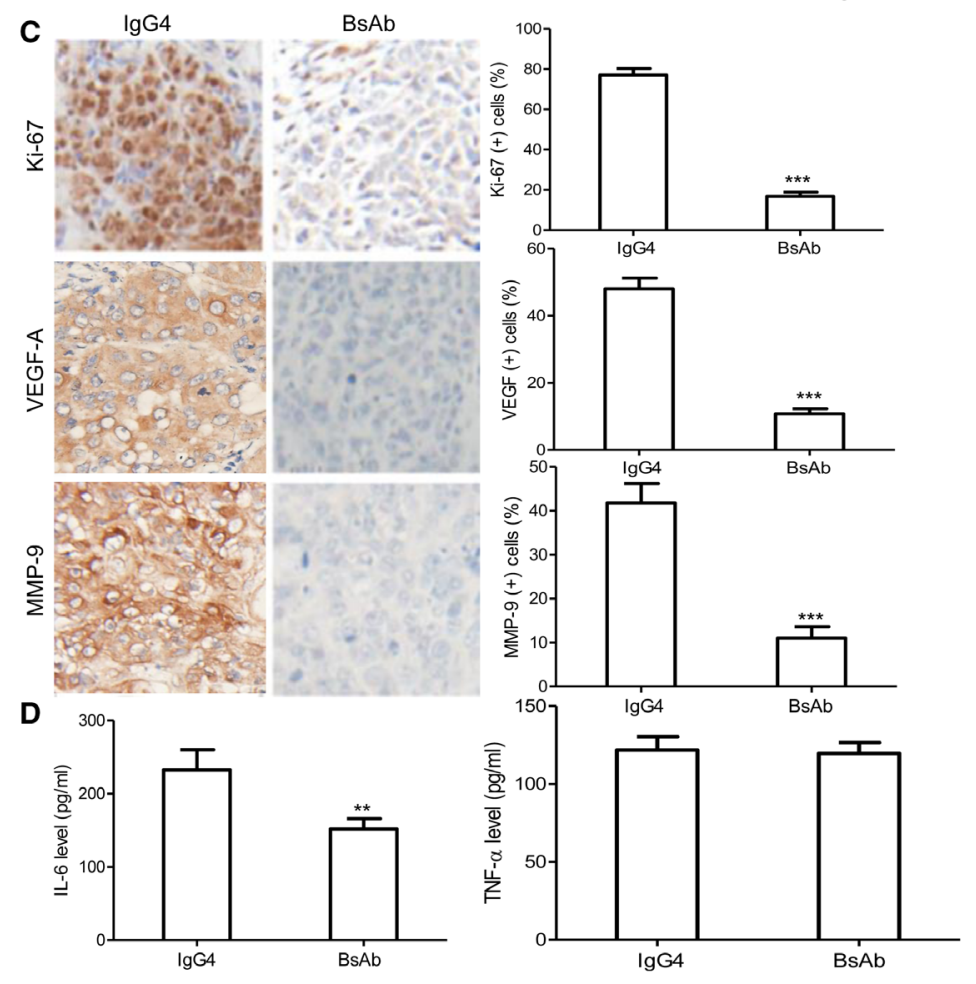

Figure 6: BsAb inhibits tumor development and chronic inflammation in vivo. (A) Xenograft studies were performed using 5-6 week old male NOD/SCID mice ( $\mathrm{n}=4$ /per group), by subcutaneous injection of MKN45 cells $\left(5 \times 10^{6}\right.$ cells). Tumor volumes measured on indicated days were plotted for the BsAb treatment and control groups. (B) MKN45 tumor xenografts were stripped 4 days after the last treatment. (C) Semi-quantification of IHC was expressed as percentage of positively stained cells. Representative images of tumors from 5 fields randomly were counted ( $n=4 /$ per group), showing Ki-67, VEGF-A, and MMP-9 (magnification: 400×). (D) Serum levels of IL-6 and TNF- $\alpha$ were measured by ELISA. The assays were repeated 2 times and each sample has 3 holes, data represent the mean \pm SD of 4 individual mice per group. **: $P<0.01 ; * *: P<0.001$
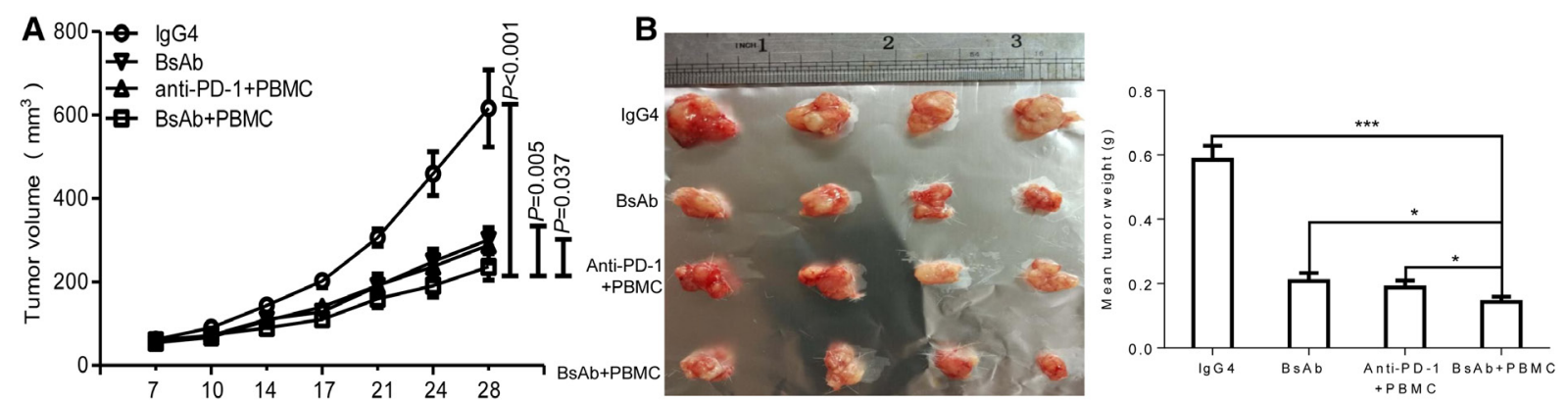

Figure 7: The therapeutic effect of BsAb exceeds that of PD-1 antibody in xenograft mice. (A) Xenograft studies were performed using 5-6 week old male NOD/SCID mice ( $\mathrm{n}=4$ /per group) by subcutaneous injection of MKN45 cells $\left(5 \times 10^{6}\right.$ cells). Tumor volumes, measured on indicated days, were plotted for each treatment group and the control group. (B) Tumor xenografts from MKN45 were stripped 4 days after the last treatment. The assays were repeated 2 times and data represent the mean \pm SD of 4 individual mice per group. *: $P<0.05 ; * * * * *: P<0.001$. 
phosphorylated AKT and ERK1/2 are the two major c-MET downstream oncogenic signaling proteins [52]. PI3K/AKT signaling activation, shown to mediate essential anti-apoptosis signals, has also been reported to be critical for cell dissociation [53, 54], and p38MAPK, along with ERK1/2, promoted HGF-mediated cornea epithelial cell migration [55]. Therefore, we could conclude that BsAb inhibits the pathways of c-MET, including AKT and ERK1/2, which may contribute to the antigrowth, antimigration, and proapoptosis effects. At the same time, analysis of the effect of BsAb on c-MET protein levels suggests that BsAb can induce protein degradation, in both dose- and time-dependent manners, in cancer cells (including MKN45 and A549 cells). We also found that BsAb didn't affect the c-MET mRNA expression levels in the two cell lines (Figure 4C, 4D), which suggested that the c-MET protein degradation may result from BsAb-mediated receptor internalization in post-transcription. However, the molecular mechanisms by which pathways promote BsAb-mediated degradation of c-MET protein require further clarification in cancer cells. In sum, these data support the conclusion that BsAb neutralizes c-MET activation, not only by blocking c-MET downstream oncogenic signaling activation, but also by reducing c-MET protein levels.

Effectively activated tumor reactive $\mathrm{T}$ cells, and suppressed checkpoint inhibitors, have resulted in prolonged tumor regression and improved overall response rates in melanoma, renal cell cancers, and lung cancers [56]. Recently, immunotherapy by checkpoint blockade directed against the PD-1/PD-L1 pathway has shown remarkable antitumor responses in patients with advanced melanoma, lung cancer, and other cancers with durable clinical responses $[23,25,57,58]$. $T$ cells activated in the absence of PD-L1/PD-1 costimulation are functionally activated, and produce higher levels of Th1 cytokines, in particular IL2 , TNF- $\alpha$, and IFN- $\gamma$ [59]. IFN- $\gamma$ could upregulate PD-L1 expression on many cell lines. In our study, we described, for the first time, a new approach to inhibit PD-1/PD-L1 costimulation by directly targeting PD-1 expression in Jurkat $\mathrm{T}$ cells using our BsAb. We observed that Jurkat $\mathrm{T}$ cells express PD-1 at low levels, but approximately $36 \%$ of Jurkat T cells expressed PD-1 after stimulation with PHA for $48 \mathrm{~h}$ (Figure 5A), and we have also observed that MKN45 and A549 cells retained remarkably upregulation PD-L1expression when stimulated with IFN- $\gamma$ (Figure 5B). The results showed that our BsAb can significantly rescue Jurkat T cell IL-2 production, which is a key cytokine indispensable to the proliferation and survival of activated $\mathrm{T}$ cells. In addition, cancer cells pretreated with IFN- $\gamma$ obviously inhibited IL-2 secretion by Jurkat T cells. It is well known that cancer cells might encounter IFN- $\gamma$ produced by activated $\mathrm{T}$ cells in the tumor's local microenvironment, and thus could respond by upregulating PD-L1 on their cell membrane to suppress T cell secretion of IL-2. Our results demonstrate that BsAb can rescue PD-L1/PD-1-mediated inhibition of IL-2 in a tumor microenvironment, which may play an important role in activating effector $\mathrm{T}$ cells by blocking PD-L1/PD-1 signaling.

At the end of the study, we examined the effect of our novel humanized BsAb on tumor growth in vivo using a xenograft model. Our results demonstrated that $\mathrm{BsAb}$ effectively inhibited tumor growth in vivo, it reduced the tumor volume and weight near $60 \%$ (Figure 6A, 6B). We also found that $\mathrm{BsAb}$ can reduce the expression of proliferation, angiogenesis, migration, and invasion-related proteins, including Ki-67, VEGF-A, and MMP-9, which indicates its potent ability to inhibit cancer cell proliferation, angiogenesis, migration, and invasion in vivo. TNF- $\alpha$, and IL-6 are produced in the microenvironment of the tumor as a result of the nonspecific inflammatory response, which appears to increase c-MET expression [60]. Further investigation showed that BsAb could strongly inhibit inflammatory factor production in vivo compared with control mice, including IL-6, although TNF- $\alpha$ was not reduced by $\mathrm{BsAb}$, which may alleviate chronic inflammation during the progress of tumor treatment.

Our BsAbs can simultaneously bind human c-MET and PD-1 with high affinity and specificity, which should achieve synergistic effects. In this study, we found that $\mathrm{BsAb}+\mathrm{PBMC}$ treatment is superior to anti-PD-1 + PBMC treatment at inhibiting tumor growth in vivo (Figure 7A) $(P=0.037)$. We also explored the effect of c-MET antibody in the inhibition of tumor growth in vivo, however, it proved difficult (data not shown), which might be due to intrinsic agonistic activity. NOD/SCID mice are deficient of humanized PD-1 highly expressing $\mathrm{T}$ cells, so our BsAb targeting the PD-1 pathway may be useless in treating mice alone. In order to simulate c-MET antibody effects, $\mathrm{BsAb}$ was used alone in treating $\mathrm{NOD} /$ SCID mice, which may simulate a monovalent form of c-MET antibody, similar to OA5D5. The results showed that $\mathrm{BsAb}+\mathrm{PBMC}$ treatment is superior to $\mathrm{BsAb}$ alone at inhibiting tumor growth in vivo $(P=0.005)$ (Figure 7A, 7B). At the same time, the safety of c-MET/PD-1 BsAb in HUVEC cell viability was done by MTS assay. There were no significant difference between BsAb and IgG4 treatment (Supplementary Figure 1).

Nevertheless, our study did not directly address the effects of BsAb comparing with one-armed c-MET antibody in vivo. Only through comparing with the antibody, could we conclude that the BsAb is indeed superior to the one-armed c-MET antibody. Further studies are necessary to explore the hypothesized superiority of BsAb over c-MET antibody in vitro and in vivo. In addition, our observation of BsAb treatment was only limited to c-MET and PD-L1-positive tumor cells, however, we do not know whether BsAb has effects in c-MET and PD-L1-negative tumor cells. In order to obtain large numbers of humanized PD-1 highly expressing T cells, reconstituting the immune systems, human PBMC were transplanted into NOD/SCID mice by tail vein injection. However, the mice may have developed host 
versus graft disease (HVGD), which may influence the effect of BsAb treatment in mice.

In conclusion, BsAb treatment strongly inhibited the growth of cancer cells in vitro and in vivo, more effectively than PD-1 antibody or simulated one-armed c-MET antibody. Mechanisms responsible for this antitumor effect include inhibition of tumor cell proliferation, migration, angiogenesis, and proinflammatory cytokine secretion, as well as proapoptotic effects, which may block c-MET downstream signaling in the AKT and ERK1/2 signaling pathways, and the PD-L1/PD-1 signaling pathway. Therefore, our studies identified BsAb to be a potential antitumor agent that may be able to effectively complement immunotherapy strategies in future.

\section{MATERIALS AND METHODS}

\section{Cell lines and cell culture conditions}

MKN45, A549, HT-29, MDA-MB-231, 769P, and Jurkat T cells were obtained from the ATCC; IM95 cell line was obtained from JCRB Cell Bank; HN30 was a gift from the Department of Oral and Maxillofacial-Head and Neck Oncology (Shanghai Jiao Tong University School of Medicine, China); Human uveal melanoma 92.1 was a gift from the Institute of Eye Vision, Shanghai Jiao Tong University School of Medicine. HN30, 92.1, MKN45, A549, HT-29, MDA-MB-231, 769P, and IM95 were cultured in DMEM (IM95 containing 1\% insulin) and Jurkat T cells cultured in RPMI- 1640 supplemented with $10 \%$ FBS (GIBCO) and of 1\% penicillin/streptomycin (GIBCO). Cells were incubated at a $37^{\circ} \mathrm{C}$ humidified incubator containing $5 \% \mathrm{CO}_{2}$.

\section{Reagents and antibodies}

Human recombinant HGF, PHA, and IFN- $\gamma$ were purchased from GenScript (Nanjing, China). The c-MET kinase inhibitors JNJ38877605 and rapamycin were obtained from Selleckchem (Houston, TX). Antibodies used include: c-MET mAb (\#8198), phospho-MET (Tyr1234/1235) mAb (\#3077), AKT mAb (\#9272), phospho-AKT (Ser473) mAb (\#4060), p44/42 MAP kinase mAb (\#4696), phospho-p44/42 MAP kinase (Thr202/ Tyr204) mAb (\#4376), GAPDH mAb (\#2118). Anti-mouse IgG, HRP-linked antibody (\#7076), anti-human IgG4 was used as control, HRP-linked antibody (\#7074) were used as secondary antibodies. All antibodies were purchased from Cell Signaling Technology, Inc. PE-labled mouse antihuman PD-1antibody was purchased from Abcam.

\section{RNA isolation and real-time quantitative PCR (qPCR)}

Total RNA was isolated from each cell line with TriReagent (Sigma-Aldrich) according to the manufacturer's instructions. cDNA synthesis and qPCR

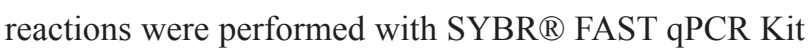
Master Mix (KAPA). The primer pairs used were: c-MET, forward 5'-TTC-ACC-GCG-GAA-ACA-CCC-ATC-3', reverse 5'-GTC-TTC-CAG-CCA-GGC-CCA-3'; PD-L1, forward 5'-TGG-CAT-TTG-CTG-AAC-GCA-TTT3', reverse 5'-GTG-GTG-GTC-TTA-CCA-CTC-AGG3'; GAPDH, forward 5'-CAT-CTC-TGC-CCC-CTC-TGCTGA-3', reverse 5'-GGA-TGA-CCT-TGC-CCA-CAGCCT-3'. $\triangle \mathrm{CT}$ (cycle threshold) values were calculated based on the mean CT values of the target genes and mean CT values of the reference control gene GAPDH, using the following formula: $\triangle \mathrm{CT}=$ Mean $\mathrm{CT}$ for Target Gene - Mean CT for GAPDH. Relative gene expression levels were calculated using $\Delta \Delta \mathrm{CT}$ analysis. $\Delta \Delta \mathrm{CT}=\Delta \mathrm{CT}$ of Sample $-\Delta \mathrm{CT}$ of Calibrator. Relative Gene Expression $=2^{-(\Delta \Delta \mathrm{CT})}$.

\section{Cell viability and apoptosis assay}

Cells were seeded in a 96-well plate at $1 \times 10^{4}$ each hole overnight and were grown in the presence of IgG4 (control) and BsAb for $8 \mathrm{~h}$ and JNJ for $2 \mathrm{~h}$, then were treated with HGF. After 3 day, $20 \mu$ MTS (Sango, China) was added to each sample and incubated for $4 \mathrm{~h}$. The absorbance of solution was recorded at $490 \mathrm{~nm}$ with a thermo microplate reader. The results of the MTS assay to reflect cell viability.

Apoptotic cells were measured by flow cytometry as follows: cells were harvested and washed with PBS, resuspended in pre-diluted binding buffer, and stained with annexinV-FITC (BD Biosciences, CA, USA) for $30 \mathrm{~min}$ at room temperature. After being washed and resuspended in PI binding buffer, the cells were immediately subjected to apoptosis analyses by flow cytometry using Cell Quest Software.

\section{In vitro scratch wound healing migration assay}

MKN45 or A549 cells were plated in a 6-well plate. After overnight a sterile $10 \mu \mathrm{l}$ pipette tip was used to make a wound across a cell culture monolayer. Cells were incubated in DMEM-0\% FBS in the presence of BsAb for $8 \mathrm{~h}$ and JNJ for $2 \mathrm{~h}$, then were treated with HGF (100 $\mathrm{ng} / \mathrm{mL}$ ). Multiple photographs of the wound were taken immediately after wounding $0 \mathrm{~h}$ and $24 \mathrm{~h}$ under a phasecontrast microscopy. The efficiency of the wound healing process was determined by calculating the area of the cell gap at the indicated times (0 and 24 h), using ImageJ software. Three random images were used for each wound at each experimental point. The results are expressed as percentage of healing at $24 \mathrm{~h}$ with respect to zero time.

\section{Western blotting}

To determine the molecular mechanism of $\mathrm{HGF}$ on c-MET signaling pathway, Western blot analysis was performed to detect key proteins involved the pathway. The cells were lysed with M-PER $®$ Mammalian Protein 
Extraction (Pierce). Proteins were quantified by the BCA Protein Assay kit (Pierce) according to the manufacturer's instructions. Samples containing a total of $50 \mu \mathrm{g}$ protein were incubated at $100^{\circ} \mathrm{C}$ for $5 \mathrm{~min}$, separated by SDSpolyacrylamide gel electrophoresis, and subsequently electrotransferred onto a polyvinylidene difluoride membrane. Essential component detection in the cells was performed with antibody at overnight incubation at $4{ }^{\circ} \mathrm{C}$, and then HRP-conjugated secondary antibody (1:5,000 dilution; Pierce Chemical) was added for $1 \mathrm{~h}$ at room temperature, followed by the development of reactions in a chemiluminescent detection system. GAPDH antibody was used as the control.

\section{Human PBMC preparation and transplantation}

Blood from healthy volunteers was collected in heparinized tubes. For the isolation of PBMCs, blood was diluted 1:1 with RPMI1640 medium (vol/vol) prior to transferring into the leucosep tube. Following centrifugation (20 min, $2000 \mathrm{rpm}$ ), the PBMC layer was pooled and transferred into a $15 \mathrm{ml}$ falcon tube. The sample was washed with $10 \mathrm{ml}$ phosphate-buffered saline (PBS) and centrifuged again for $10 \mathrm{~min}$ at $1500 \mathrm{rpm}$. The obtained cell pellet was resuspended in PBS. A total of $1 \times 10^{8}$ PBMCs per mouse were injected into NOD/SCID mice through tail vein for the reconstitution of immune system.

\section{Tumor xenograft study}

Approximately 5- to 6-week male NOD/SCID mice (about $20 \mathrm{~g}$ ) were obtained from SLAC Laboratory Animal Co., Ltd. (Shanghai, China) and were kept in a specific pathogen-free (SPF) facility. They are absent of T, B lymphocytes, and NK cells. All animal treatment were in accordance with international ethics guidelines and the National Institutes of Health Care and Use of Laboratory Animals. This study was approved by the Institutional Animal Care and Use Committee of Fudan University. MKN45 cells $\left(5 \times 10^{6}\right.$ cells $)$ were subcutaneously injected into the right flank region of mice. After 7 days, allowing the tumors to grow to about $50 \mathrm{~mm}^{3}$, mice were randomized into control and treatment groups. For MKN45 xenograft, mice were treated as follows: BsAb (10 mg/kg, twice per week), IgG4 and anti-PD-1 (5 mg/ $\mathrm{kg}$, twice per week); PBMCs $\left(1 \times 10^{8}\right)$ were injected the first and fourth time drugs were administered through via tail vein. Each group consisted of 5-6 mice. At the same time, body weight and tumor size were measured using an electronic balance and a vernier caliper. Tumor volume was calculated using the formula: volume = $\left(\right.$ length $\times$ width $\left.^{2}\right) \times 0.5$. After the endpoint $(28$ days after the implantation), blood was collected from the aorta abdominalis and the serum was separated and frozen at $-80^{\circ} \mathrm{C}$ for further analyses. Mice were then sacrificed for the collection of tumors.

\section{Immunohistochemistry (IHC)}

Tumor samples were fixed in $4 \%$ formalin, embedded in paraffin, and sectioned into 4- $\mu$ m-thickness slices. After dewaxing, tissues sections were processed by antigen retrieval, followed by the quenching of endogenous peroxidase activity using hydrogen peroxide. PBS $(0.1 \%$ Tween 20$)$ containing anti-goat serum was used to block non-specific binding sites. Slides were incubated with polyclonal antibodies against Ki-67 or VEGF-A or MMP-9 (in 1:100 dilution, CST, US). After washing with PBS, slides were incubated with biotinylated anti-rabbit IgG antibody followed by horseradish peroxidase-conjugated streptavidin. After developing in DAB substrates (Invitrogen, US), 5 highmagnification fields were randomly selected in each slide, and the numbers of positive cells in each field were counted (each group=4) by the image analysis system (Image-Pro Plus).

\section{ELISA}

The cytokines levels of IL-2 (culture supernatants), TNF-a, and IL-6 (mice serum) were measured using the specific ELISA kits (R\&D Systems) following the manufacturer's instructions.

\section{Statistical analysis}

The statistical analysis between groups was performed using GraphPad Prism 5 software. The unpaired 2-tailed $t$ test was used for the comparison and the level of significance was defined when $P<0.05$.

\section{ACKNOWLEDGMENTS}

This work was supports by Science and Technology Commission of Shanghai Municipality 14431900100.

\section{CONFLICTS OF INTEREST}

The authors declare there are no potential conflicts of interest in regards to the present study.

\section{REFERENCES}

1. Cecchi F, Rabe DC, Bottaro DP. Targeting the HGF/ Met signaling pathway in cancer. Eur J Cancer. 2010; 46:1260-70.

2. Birchmeier C, Birchmeier W, Gherardi E, VandeWoude GF. Met, metastasis, motility and more. Nat Rev Mol Cell Biol. $2003 ; 4: 915-25$. 
3. Trusolino L, Comoglio PM. Scatter-factor and semaphoring receptors: cell signalling for invasive growth. Nat Rev Cancer. 2002; 2:289-300.

4. Maulik G, Shrikhande A, KijimaT, Ma PC, Morrison PT, Salgia R. Role of the hepatocyte growth factor receptor, c-Met, in oncogenesis and potential for therapeutic inhibition. Cytokine Growth Factor Rev. 2002; 13:41-59.

5. Laterra J, Nam M, Rosen E, Rao JS, Lamszus K, Goldberg ID, Johnston P. Scatter factor/hepatocyte growth factor gene transfer enhances glioma growth and angiogenesis in vivo. Lab Invest. 1997; 76:565-77.

6. Lamszus K, Laterra J, Westphal M, Rosen EM. Scatter factor/hepatocyte growth factor (SF/HGF) content and function in human gliomas. Int J Dev Neurosci. 1999; 17:517-30.

7. Rosen EM, Laterra J, Joseph A, Jin L, Fuchs A, Way D, Wittle M, Weinand M, Goldberg ID. Scatter factor expression and regulation in human glial tumors. Int $\mathrm{J}$ Cancer. 1996; 67:248-55.

8. Koochekpour S, Jeffers M, RulongS, Taylor G, Klineberg E, Hudson EA, Resau JH, VandeWoude GF. Met and hepatocyte growth factor/scatter factor expression in human gliomas. Cancer Res. 1997; 57:5391-8.

9. MoriyamaT, Kataoka H, Kawano H, Yokogami K, Nakano S, Goya T, Uchino H, Koono M, Wakisaka S. Comparative analysis of expression of hepatocyte growth factor and its receptor, c-met, in gliomas, meningiomas and schwannomas in humans. Cancer Lett. 1998; 124:149-55.

10. Schmidt NO, Westphal M, Hagel C, Ergün S, Stavrou D, Rosen EM, Lamszus K. Levels of vascular endothelial growth factor, hepatocyte growth factor/scatter factor, and basic fibroblast growth factor in human gliomas and their relation to angiogenesis. Int J Cancer. 1999; 84:10-8.

11. Cao R, Björndahl MA, Gallego MI, Chen S, Religa $\mathrm{P}$, Hansen AJ, Cao Y. Hepatocyte growth factor is a lymphangiogenic factor with an indirect mechanism of action. Blood. 2006; 107:3531-36.

12. Agwa ES, Ma PC. Targeting the MET receptor tyrosine kinase in non-small cell lung cancer: emerging role of tivantinib. Cancer Manag Res. 2014; 6:397-404.

13. Basilico C, Pennacchietti S, Vigna E, Chiriaco C, Arena S, Bardelli A, Valdembri D, Serini G, Michieli P. Tivantinib (ARQ197) displays cytotoxic activity that is independent of its ability to bind MET. Clin Cancer Res. 2013; 19:2381-92.

14. Cui JJ, Shen H, Tran-Dubé M, Nambu M, McTigue M, Grodsky N, Ryan K, Yamazaki S, Aguirre S, Parker M, Li Q, Zou H, Christensen J. Lessons from (S)-6-(1-(6-(1methyl-1H-pyrazol-4-yl)-[1,2,4]triazolo[4,3-b]pyridazin3-yl)ethyl)quinoline(PF-04254644), an inhibitor of receptor tyrosine kinase c-Met with high protein kinase selectivity but broad phosphodiesterase family inhibition leading to myocardial degeneration in rats. J Med Chem. 2013; 56:6651-65.

15. Buchanan SG, Hendle J, Lee PS, Smith CR, Bounaud PY, Jessen KA, Tang CM, Huser NH, Felce JD, Froning KJ,
Peterman MC, Aubol BE, Gessert SF, et al. SGX523 is an exquisitely selective, ATP-competitive inhibitor of the MET receptor tyrosine kinase with antitumor activity in vivo. Mol Cancer Ther. 2009; 8:3181-90.

16. Steinig AG, Li AH, Wang J, Chen X, Dong H, Ferraro C, Jin M, Kadalbjoo M, Kleinberg A, Stolz KM, Tavares-Greco PA, Wang T, Albertella MR, et al. Novel 6-aminofuro[3,2-c] pyridines as potent, orally efficacious inhibitors of cMET and RON kinases. Bioorg Med Chem Lett. 2013; 23:4381-7.

17. Prat M, Crepaldi T, Pennacchietti S, Bussolino F, Comoglio PM. Agonistic monoclonal antibodies against the Met receptor dissect the biological responses to HGF. J Cell Sci. 1998; 111:237-47.

18. Ohashi K, Marion PL, Nakai H, Meuse L, Cullen JM, Bordier BB, Schwall R, Greenberg HB, Glenn JS, Kay MA. Sustained survival of human hepatocytes in mice: A model for in vivo infection with human hepatitis B and hepatitis viruses. Nat Med. 2000; 6:327-31.

19. Keir ME, Butte MJ, Freeman GJ, Sharpe AH. PD-1 and its ligands in tolerance and immunity. Annu Rev Immunol. 2008; 26:677-704.

20. Sznol M, Chen L. Antagonist antibodies to PD-1 and B7-H1 (PD-L1) in the treatment of advanced human cancer. Clin Cancer Res. 2013; 19:1021-34.

21. Punkosdy GA, Blain M, Glass DD, Lozano MM, O'Mara L, Dudley JP, Shevach EM. Regulatory T-cell expansion during chronic viral infection is dependent on endogenous retroviral superantigens. Proc Natl Acad Sci USA. 2011; 108:3677-82.

22. Wenshi, Wang, Roy Lau, Daohai Yu, Weiwei Zhu, Alan Korman, Jeffrey Weber. PD1 blockade reverses the suppression of melanoma antigen-specific CTL byCD4 ${ }^{+} \mathrm{CD} 25$ (Hi) regulatory T cells. Int Immunol. 2009; 21:1065-77.

23. Pardoll DM. The blockade of immune checkpoints in cancer immunotherapy. Nat Rev Cancer. 2012; 12:252-64.

24. Haile ST, Horn LA, Ostrand-Rosenberg S. A soluble form of CD80 enhances antitumor immunity by neutralizing ligand-1 and simultaneously providing costimulation. Cancer Immunol Res. 2014; 2:610-5.

25. Topalian SL, Hodi FS, Brahmer JR, Gettinger SN, Smith DC, McDermott DF, Powderly JD, Carvajal RD, Sosman JA, Atkins MB, Leming PD, Spigel DR, Antonia SJ, et al. Safety, activity, and immune correlates of anti-PD-1 antibody in cancer. N Engl J Med. 2012; 366:2443-54.

26. Le DT, Uram JN, Wang H, Bartlett BR, Kemberling H, Eyring AD, Luber BS, AzadNS, Laheru D, Biedrzycki B, Donehower RC, Zaheer A, Fisher GA, et al. PD-1 blockade in tumors with mismatch-repair deficiency. N Engl J Med. 2015; 372:2509-20.

27. Brahmer J, Reckamp KL, Baas P, Crino L, Eberhardt WE, Poddubskaya E, Antonia S, Pluzanski A, Vokes EE, Holgado E, Waterhouse D, Ready N, Gainor J, et al. Nivolumab versus docetaxel in advanced squamous cell non-small-cell lung cancer. N Engl J Med. 2015; 373:123-35. 
28. Garon EB, Rizvi NA, Hui R, Leighl N, Balmanoukian AS, Eder JP, Patnaik A, Aqqarwal C, Gubens M, Horn L, Carcereny E, Ahn MJ, Felip E, et al. Pembrolizumab for the treatment of non-small cell lung cancer. N Engl J Med. 2015; 372:2018-28.

29. Herbst RS, Soria JC, Kowanetz M, Fine GD, Hamid O, Gordon MS, Sosman JA, McDermott DF, Powderly, JD, Gettinger SN, Kohrt HE, Horn L, Lawrence DP, et al. Predictive correlates of response to the anti-PD-L1 antibody MPDL3280A in cancer patients. Nature. 2014; 515:563-7.

30. Scott LJ. Nivolumab: A Review in advanced melanoma. Drugs. 2015; 75:1413-24.

31. Sullivan RJ, Flaherty KT. Pembrolizumab for treatment of patients with advancedor unresectable melanoma. Clin Cancer Res. 2015; 21:2892-7.

32. Wolchok JD, Kluger H, Callahan MK, Postow MA, Rizvi NA, Lesokhin AM, Segal NH, Ariyan CE, Gordon RA, Reed K, Burke MM, Caldwell A, Kronenberg SA, et al. Nivolumab plus ipilimumab in advanced melanoma. N Engl J Med. 2013; 369:122-33.

33. Postow MA, Chesney J, Pavlick AC, Robert C, Grossmann K, McDermott D, Linette GP, Meyer N, Giguere JK, Agarwala SS, Shaheen M, Ernstoff MS, Minor D, et al. Nivolumab and ipilimumab versus ipilimumab in untreated melanoma. N Engl J Med. 2015; 372:2006-17.

34. Larkin J, Chiarion-Sileni V, Gonzalez R, Grob JJ, Cowey CL, Lao CD, Schadendorf D, Dummer R, Smylie M, Rutkowski P, Ferrucci PF, Hill A, Wagstaff J, et al. Combined Nivolumab and Ipilimumab or Monotherapy in Untreated Melanoma. N Engl J Med. 2015; 373:23-34.

35. Lynch TJ, Bondarenko I, Luft A, Serwatowski P, Barlesi F, Chacko R, Sebastian M, Neal J, Lu H, Cuillerot JM, Reck M. Ipilimumab in combination with paclitaxel and carboplatin as first-line treatment in stage IIIB/IV nonsmall-cell lung cancer: results from a randomized, doubleblind, multicenter phase II study. J Clin Oncol. 2012; 30:2046-54.

36. Pen JJ, Keersmaecker BD, Heirman C, Corthals J, Liechtenstein T, Escors D, Thielemans K, Breckpot K. Interference with PD-L1/PD-1 co-stimulation during antigen presentation enhances the multifunctionality of antigen-specific T cells. Gene Ther. 2014; 21:262-71.

37. Balan M, Mier y Teran E, Waaqa-Gasser AM, Gasser M, Choueiri TK, Freeman G, Pal S. Novel roles of c-MET in the survival of renal cancer cells through the regulation of HO-1 and PD-L1 expression. J Biol Chem. 2015; 290:8110-20.

38. Liu Y, Liu JH, Chai K, Tashiro S, Onodera S andIkejima T. Inhibition of c-Met promoted apoptosis, autophagy and loss of the mitochondrial transmembrane potential in oridonininduced A549 lung cancer cells. J Pharm Pharmacol. 2013; 65:1622-42.

39. Steinway SN, Dang H, You H, Rountree CB, Ding W. The EGFR/ErbB3 pathway acts as a compensatory survival mechanism upon c-Met inhibition in human c-Met ${ }^{+}$ hepatocellular carcinoma. PLoS One. 2015; 10:1-16.

40. Cao HH, Cheng CY, Su T, Fu XQ, Guo H, Li T, Tse AK, Kwan HY, Yu H, Yu ZL. Quercetin inhibits HGF/c-MET signaling and HGF-stimulated melanoma cell migration and invasion. Mol Cancer. 2015; 14:103-14.

41. Dhimolea E, Reichert JM. World bispecific antibody summit, September 27-28, 2011, Boston, MA. MAbs. 2012; 4:4-13.

42. Castoldi R, Ecker V, Wiehle L, Majety M, Busl-Schuller R, Asmussen M, Nopora A, Jucknischke U, Osl F, Kobold S, Scheuer W, Venturi M, Klein C, Niederfellner G, Sustmann C. A novel bispecific EGFR/Met antibody blocks tumor-promoting phenotypic effects induced by resistance to EGFR inhibition and has potent antitumor activity. Oncogene. 2013; 32:5593-601.

43. Bok-Soon Lee, Haeng-Jun Kim, Jae-Woong Hwang, Kwang Ho Cheong, Kyung-Ah Kim, Hyun-Young Cha, Ji Min Lee, Chul-Ho Kim. The dual inhibition of Met and EGFR by ME22S, a novel Met/EGFR bispecific monoclonal antibody, suppresses the proliferation and invasion of laryngeal cancer. Ann Surg Oncol. 2016, 23:2046-53.

44. Moores SL, Chiu ML, Bushey BS, Chevalier K, Luistro L, Dorn K, Brezski RJ, Haytko P, Kelly T, Wu SJ, Martin PL, Neijssen J, Parren PW, et al. A Novel Bispecific Antibody Targeting EGFR and cMet Is Effective against EGFR Inhibitor-Resistant Lung Tumors. Cancer Res. 2016, 76:3942-53.

45. Fan G, Wang Z, Hao M, Li J. Bispecific antibodies and their applications. J Hematol Oncol. 2015; 8:130-43.

46. Kontermann RE, Brinkmann U. Bispecific antibodies. Drug Discov Today. 2015, 20:838-47.

47. Prat M, Crepaldi T, Pennacchietti S, Bussolino F, Comoglio PM. Agonistic monoclonal antibodies against the Met receptor dissect the biological responses to HGF. J Cell Sci. 1998; 111:237-47.

48. Ohashi K, Marion PL, Nakai H, Meuse L, Cullen JM, Bordier BB, Schwall R, Greenberg HB, Glenn JS, Kay MA. Sustained survival of human hepatocytes in mice: A model for in vivo infection with human hepatitis B and hepatitis delta viruses. Nat Med. 2000; 6:327-31.

49. Nguyen TH, Loux N, Dagher I, Vons C, Carey K, Briand P, Hadchouel M, Franco D, Jouanneau J, Schwall R, Weber A. Improved gene transfer selectivity to hepatocarcinoma cells by retrovirus vector displaying single-chain variable fragment antibody against c-Met. Cancer Gene Ther. 2003; 10:840-9.

50. Martens T, Schmidt NO, Eckerich C, Fillbrandt R, Merchant M, Schwall R, Westphal M, Lamszus K. A novel oneArmed anti-c-Met antibody inhibits glioblastoma growth in vivo. Clin Cancer Res. 2006; 12:6144-52.

51. Pacchiana G, Chiriaco C, Stella MC, Petronzelli F, De Santis R, Galluzzo M, Carminati P, Comoglio PM, Michieli P, Vigna E. Monovalency unleashes the full therapeutic 
potential of the DN-30 anti-Met antibody. J Biol Chem. 2010; 285:36149-57.

52. Liu X, Newton RC, Scherle PA. Developing c-MET pathway inhibitors for cancer therapy: progress and challenges. Trends Mol Med. 2010; 16:37-45.

53. Martínez-Palacián A, del Castillo G, Suárez-Causado A, García-Álvaro M, de Morena-Frutos D, Fernández M, Roncero C, Fabregat I, Herrera B, Sánchez A. Mouse hepatic oval cells require Met-dependent PI3K to impair TGF- $\beta$-induced oxidative stress and apoptosis. PLoS One. 2013; 8:123-31.

54. Schulze-Bergkamen H, Brenner D, Krueger A, Suess D, Fas SC, Frey CR, Dax A, Zink D, Büchler P, Müller M, Krammer PH. Hepatocyte growth factor induces Mcl-1 in primary human hepatocytes and inhibits CD95-mediated apoptosis via Akt. Hepatology. 2004; 39:645-54.

55. Royall, Park M. Hepatocyte growth factor-induced scatter of Madin-Darby canine kidney cells requires phosphatidylinositol 3-kinase. J Biol Chem. 1995; 270:27780-7.

56. Chatterjee S, Lesniak WG, Gabrielson M, Lisok A, Wharram B, Sysa-Shah P, Azad BB, Pomper MG, Nimmagadda $\mathrm{S}$. A humanized antibody for imaging immune checkpoint ligand PD-L1 expression in tumors. Oncotarget. 2016; 7:10215-27. doi: 10.18632/oncotarget.7143.
57. Berger R, Rotem-Yehudar R, Slama G, Landes S, Kneller A, Leiba M, Koren-Michowitz M, Shimoni A, Nagler A. Phase I safety and pharmacokinetic study of CT-011, a humanized antibody interacting with PD-1, in patients with advanced hematologic malignancies. Clin Cancer Res. 2008; 14:3044-51.

58. Brahmer JR, Tykodi SS, Chow LQ, Hwu WJ, Topalian SL, Hwu P, Drake CG, Camacho LH, Kauh J, Odunsi K, Pitot HC, Hamid O, Bhatia S, Martins R, Eaton K, Chen S, et al. Safety and activity of anti-PD-L1 antibody in patients with advanced cancer. N Engl J Med. 2012; 366:2455-65.

59. Wong RM, Scotland RR, Lau RL, Wang C, Korman AJ, Kast WM, Weber JS. Programmed death-1 blockade enhances expansion and functional capacity of human melanoma antigen specific CTLs. Int Immunol. 2007; 19:1223-34.

60. Moghul A, Lin L, Beedle A, Kanbour-Shakir A, DeFrances MC, Liu Y, Zarnegar R. Modulation of c-MET protooncogene (HGF receptor) mRNA abundance by cytokines and hormones: evidence for rapid decay of the $8 \mathrm{~kb}$ c-MET transcript. Oncogene. 1994; 9:2045-52. 